\title{
DRD4 wt Allele
}

National Cancer Institute

\section{Source}

National Cancer Institute. DRD4 wt Allele. NCI Thesaurus. Code C51441.

Human DRD4 wild-type allele is located in the vicinity of 11 p15.5 and is approximately 3 $\mathrm{kb}$ in length. This allele, which encodes $\mathrm{D}(4)$ dopamine receptor protein, is involved in the inhibition of adenylyl cyclase activity. Mutations in the gene have been associated with various behavioral phenotypes. 